\title{
The Role of Art Practice in Elementary School Science
}

\section{Cecilia Caiman $^{1} \cdot$ Britt Jakobson $^{1}$}

Published online: 28 February 2019

(C) The Author(s) 2019

\begin{abstract}
The aim of this study was to examine the role of aesthetic practice in elementary school and the consequences for children's meaning-making in science. More specifically, we intended to scrutinise what science learning emerges within the process, to target the consequences of adopting art practice in science class and to explore these two dimensions as a whole in order to better understand how children make meaning when exploring animals' ecology. The data, comprising audio recordings, photographs of children's drawings and field notes, were collected in one school which we visited on three occasions over a period of four consecutive days. The school is located in Sweden, and the children participating in the study were between 6 and 7 years old (Swedish grade 1). In this particular study, the children were involved in exploring animals' ecology. Data was analysed by means of practical epistemology analysis (PEA), taking its stance in Deweyan pragmatic philosophy on learning and meaningmaking. The results reveal that art practice was important for children's cognitive and aesthetic learning in science. The entanglement of science learning and art-in-the-making was shown to be of significance for broadening and deepening children's science repertoire. In addition, children's imagination and creativity was a vital part of their meaning-making when exploring a complex phenomenon, such as the spinneret, the "spider-thread machine". All along the process, the young learners, in transaction with the contextual features, developed agency meaning that the children owned the problems and developed action strategies through art and speech.
\end{abstract}

Keywords Artpractice. Science $\cdot$ Meaning-making Imagination $\cdot$ Aesthetics $\cdot$ Elementary school children

Cecilia Caiman

cecilia.caiman@mnd.su.se

1 Department of Mathematics and Science Education, Stockholm University, S-106 91 Stockholm, Sweden 


\section{Introduction}

In this study, we scrutinise the role of art practice in elementary school and the consequences for children's meaning-making in science. Units and projects within early years' elementary school science frequently involve art, such as drawing, sculpturing and drama. However, several studies of students' artwork in science class underpin the cognitive dimension but seem to overlook the significance of a focus that simultaneously takes into consideration science-inthe-making and drawing-in-the-making. Learning science is not only a question of conceptual understanding, but also dealing with children's opportunities to participate purposefully and, thus, to develop a sense of belonging in scientific practice. In this study, we pay specific attention to the role of art practice, that is, doing art in ongoing processes which include different ways of communication. In addition, we study the ways in which participation can be seen through aesthetic experience. The purpose of this study is to scrutinise what science learning emerges within the process, to target the consequences of adopting art practice in science class and to explore these two dimensions as a whole in order to better understand how children make meaning when exploring animals' ecology.

\subsection{Young Children Learning Science-an Educational Challenge}

Scholars have argued that student-driven, hands-on activities enhance young children's learning and meaning-making in science (Siry and Kremer 2011; Siry et al. 2012; Goulart and Roth 2010). They have stressed the importance of encouraging children to explore science as something that emerges, contrary to learning ready-made scientific facts and concepts (cf. Goulart and Roth 2010). Similarly, Olsson et al. (2016) emphasised learning as an aesthetic and "processual" event. In this process, young children's production of different logics may arise, leading to inventiveness that can push the limit of what science might be. To position children as active, agentive participants suggest the need for rearranging the child-teacher relationship (Caiman and Lundegård 2014). Taking young children's curiosity, wonderings and problems-under-construction seriously (Olsson 2013) is a challenge as it addresses to what extent teachers' radical, thorough, listening is practiced in science class (Bateson 1971; Siry and Brendel 2016). Attuning to children's voices and their concerns is consequently a way of challenging the asymmetric relation that can occur when adults and young children are involved in cooperative events (Vecchi 2010). Being attentive to children's voices is also emphasised in the early work of Bronson Alcott (1836/1991). Teachers need to support children's ideas by carefully listening as "best thoughts do not lie on the surface" (Bronson Alcott 1836/1991, p. 1). Besides, when adopting a "listening" approach, the concern is the significance of including other communicative resources than just language, such as art practice, in order to grasp the complexity of young children's meaning-making in science (Caiman 2015).

\subsection{Aesthetics and Science Learning}

There is overall a lack of research on the role of students' aesthetics in science class and the consequences for their learning and meaning-making. Aesthetics is here partly viewed as art and partly as aesthetic experiences expressed in judgements, elaborated on later in this article (Dewey 1934/1980). Most studies are mainly concerned with cognitive aspects where conceptual understanding is privileged. A review by Wickman (2017) has revealed that most 
studies on aesthetics in science class are concerned with students' attitudes towards, motivation to and interest in science. Only $6 \%$ of aesthetic experience-based studies were conducted in situ, whereas most studies were predominantly conducted through questionnaires and interviews. Accordingly, the potential of aesthetic experiences, including art practices, has rarely been addressed and still receives sparse attention in science education research (Wickman 2017). Therefore, the educational possibility of intertwining cognitive, emotional and artistic aspects in science education is overlooked (Girod et al. 2003).

In this study, we pay specific attention to the role of art practice and children's aesthetic experiences in science class. This implies challenging art as an exclusive artistic activity, rather treating art practice as part of science-in-the-making, sometimes elaborated as emergent science (Caiman 2015; Siry et al. 2012; Larsson 2013). Accordingly, our focus is on situated processes and the consequences for science learning. Taking the oral and the visual dimensions simultaneously into consideration makes it possible to make a deeper and a more extensive analysis when studying the processes.

\subsection{Art in Science Education}

The significance of using art in science class has given rise to different approaches and lines of argument. Firstly, several scholars maintain that art in science education humanises the subjects and makes them more accessible to students (e.g. Watts 2001). Secondly, others treat art primarily as a means, for example for depicting observable scientific phenomena, often in combination with interviews, when evaluating students' conceptual understanding. This approach underpins the individual cognitive dimension in science class. Dove et al. (1999) used children's drawings as well as interviews when studying their conceptual understanding of a river basin. They claimed that it is important to talk to children about their drawings in order to identify any misconceptions that might occur. Similarly, Hulland and Munby (1994) interviewed children as a complement to examining their drawings when testing their understanding of wetlands. Another study examined young children's understanding about the human body by using children's drawings (Reiss and Tunnicliffe 2001; Reiss et al. 2002), while Teixera (2000) used both art activities and interviews when investigating children's understanding of the digestive system. Other scholars have studied student's use of multiple representational modes, such as captioned drawings combined by interviews to investigate how conceptual understanding of, for example, evaporation is developed. The results showed that various representations promote learning scientific explanations and as well function as a starting point for further science learning and clarifications (e.g. Prain et al. 2009). Furthermore, Poldberg et al. (2013) showed that elementary school children's learning about rocks benefitted from concomitant art practice. The children improved their observational skills, and most of them raised their level of advanced science vocabulary. Branched out from psychology, Kouvou (2016), given the role of children's cognitive development combined with adult's instructions of graphic strategies, revealed how children were enabled to advance their stereotype drawings towards more complex narratives.

A third approach scrutinised the contextual features and situational aspects for children's decisions and distinctions about what to include or exclude when partaking in art practices in science class. The realm of aesthetics was analysed as young children explored science and sustainability issues. The results showed that children's encounters with the physical environment, such as tiny pea plants and a bird nest, as well as their 
own sketches, allowed them to develop agency and their sense of belonging (Caiman and Lundegård 2014). Another study compared children's expressions in drawings with statements they made during interviews about the human body (Lundin and Jakobson 2014). The drawings were made prior to the interviews, and the result shows that the children gave several reasons for what they included in the drawings: social, artistic, practical, empirical and memory reasons were identified. In a study conducted by Jakobson and Wickman (2008a), both purposes - scientific and artistic - and the specific situation were shown to be of importance when elementary school children observed goldfish. Besides learning facts about fish, they learned the norms and the aesthetics of science class and the aesthetics of artwork. In another study, children participated in two activities - scientific inquiry, in which they observed leaves, and art practice, in which they rubbed leaves in different colours of paint. The two activities were found to be complementary and resulted not only in enhanced scientific learning about leaves, but also in aesthetic experiences that were expressed in aesthetic judgements about leaves and their features (Jakobson and Wickman 2015). These results suggest that adopting art practices in science class contributes to increased opportunities for children to make distinctions and decisions, thus leading to enhanced learning. In addition, making distinctions and decisions are significant aspects when children's problems of concern gain attention embedded in a "context for actions", for example various inviting milieus children explorative can act upon. Such contexts might develop agency (Biesta and Tedder 2007, p. 7).

More recently, a fourth argument about the potential of interdisciplinary approaches concerning science and art education has been proposed. In order to secure art in science education and in line with the conviction of the "transdisciplinary nature of learning", STEAM (Science, Technology, Engineering, Arts and Mathematics) has branched out from STEM (Science, Technology, Engineering and Mathematics), accentuating artistic and creative processes within those fields (Katz-Buonincontro 2018, p. 75). Similarly, Gurnon et al. (2013) have argued that science and art disciplines are entwined and fruitfully fertilise each other. Weigand (1985) concluded that when students participated in an integrated art/science class, both retained and deepened their art and science knowledge. Likewise, Gurnon et al. (2013) carried out an interdisciplinary study in which undergraduate art and science students collaborated to construct sculptures of protein chains. The result suggests that blending art and science facilitates students' curiosity, creativity, imagination and use of metaphors when learning and communicating science. Likewise, Root-Bernstein $(1991,1996)$ challenged the common view of art and science as being divided that results in a dichotomy. Conventionally, art is based on personal taste and is regarded as subjective, whereas science is seen as grounded in objective facts and rules. In this context, art, especially fine art, is approached as qualitatively different from science (Welsh 1997).

However, and on the contrary, visual art and science practices are rather closely related, as imagination, emotions, inquiry and analysis are part of both disciplines (Root-Bernstein 1996). Similarities between both artistic and scientific skills and procedures, such as spatial reasoning and observations, are stressed as vital dimensions in both practices (Gurnon et al. 2013). Other resemblances have been discussed in terms of contingent or temporal dimensions when people participate in both scientific and aesthetic practices (Wickman 2006, 2017). Although there are similarities between science and art practice, there are also differences. In science, hypothesis, theories and laws are 
mainly evidence-based, a feature that is not necessarily prominent in art. Science practice is a cumulative enterprise, whereas art is not. However, both disciplines are regarded as emergent, open and not predetermined because as humans, we always contribute our own experiences and creativity (Caiman and Lundegård 2018).

\subsection{Art- and Science-in-the-Making—a Philosophical and Practical Issue}

As our study pays attention to art- and science-in-the-making, where the art practice and its role are scrutinised, artists' and scientists' work seems to be related to how children make sense of the world. Like artists and scientists, children are often engaged in experimenting and imagining - vital when children are allowed to develop different logics and something new is created. We here outline how artists and scientists progress in their work, making it possible to closer examine how children proceed in science class. Even though the three practices have different characteristics, they are social in nature.

When specifically examining the open-ended process of creating an artwork, "the act of painting is always shifting, it is constantly oscillating between a beforehand and an afterword", according to Deleuze's (1981/2013, p. 69) writings on Francis Bacon's artwork. Similarly, the immediate and the accidental are vigorous dimensions in art production (Sylvester 1975/2016) and also have significance for scientific practice (cf. Pickering 1995; Barad 2007). In a series of conversations between Francis Bacon and the art critic David Sylvester, they jointly scrutinised how a painting arises (Sylvester 1975/ 2016). Bacon emphasised that the transformations of existing images started in his mind in terms of different predictions but were hardly ever carried out as foreseen. Rather, unplanned or contingent aspects were vital when an image emerged and transformed, which had consequences for the process, and accordingly for the outcome. The purpose changed itself through the process of painting and, for example, the large brushes which Bacon exemplified, took over, and the art work morphed into something new. The process was not per se unintended, but rather an event, a "selective process", where certain accidents and habits were chosen to be preserved (Sylvester 1975/2016, p. 14). Keeping the vitality of the accident yet preserving continuity is an important part of making art, which may be called a dynamic art event (Garoian 2013).

Returning to the act of painting, artwork itself inevitably becomes an infinite set of suggestions rather than a representation in comparison to a snapshot, such as a photo. This line of argument frequently recurred in Sylvester and Bacon's conversations on the process of art practice (Sylvester 1975/2016). In accordance, a sign in a painting is never a sign predefined or fixed in itself; rather it becomes a sign when it is used in various ways (Linde 1960, 1962). When creating an artwork, colour and form are two vital variables in the "code of painting" (Deleuze 1981/2013, p. 79), appealing to the spectators' emotions and inviting them to participate in an ongoing communication. As a result, an artwork gets its meaning in reciprocal collaboration between the spectators and the painting, or to put it differently, shared aesthetic experiences give rise to situated dialogues.

Likewise, science is based on aesthetic experiences and specific language games during science work (Wickman 2006). There are good reasons to question the divide between science and art disciplines, as scholars have recurrently suggested that visual art and science practices are closely related in terms of sensation, imagination, emotions and analysis - all vital parts of both disciplines (Root-Bernstein 1991, 1996). When engaged 
in scientific inquiry for example, dealing with the occurrence of unpredictable features, reconfiguration of materials and apparatus, analysing events and handling changeability of variables are significant parts of the activity as a whole, underscoring science as a social enterprise. On that account, human imagination and emotions are intertwined when complex science work is in-the-making.

Referring to Glasers' photos of tracks in a cloud chamber, Pickering (1995) also pointed out the role of contingency in scientific investigations, where both material and human agency partake and are interrelated. At first sight, results of investigations might seem to be happening by chance. On the contrary, the conduct of a new series of experiments and the material elements cooperatively act "in a particular way" and a new discovery might occur (Pickering 1995, p. 52). Highlighting the production of scientific knowledge, Pickering (1995 p. 70) suggested scientific investigations as "a mangling of practice". Likewise, Latour (1999) challenged science as a discipline reduced to a set of principles, arguing that science is rather an arrangement of an actor-actant symmetry, which goes beyond the fixed subject matter dichotomy. Referring to Pasteur's work on microbes that cause fermentation, Latour (1999 p. 129) raised the key question: "Who is the active force in this experiment?" His own response to the question is twofold: both the yeast and Pasteur interact; more precisely, Pasteur's actions resulted in the action of the yeast. In light of this, unpredictable features are all vital when science is in-the-making. The meticulous, historical-based descriptions of the flux of humans in conducting scientific work by both Pickering (1995) and Latour (1999) are applicable in science education.

\section{Theoretical Background}

\subsection{A Philosophy of Aesthetic Experience, Continuity and Agency}

Combining Dewey's philosophy of pragmatics, art viewed as an aesthetic practice, with Bacon's process-oriented explanation, we may see art as part of ordinary life. This challenges the idea of art as the exclusive preoccupation of certain people. According to Dewey (1934/ 1980), it is possible for all people to express and invent meanings and values through art, whereas it is not always possible to express the same in words. He argued that "art is the most effective mode of communication that exists" (Dewey 1934/1980, p. 286), pointing to the value of including visual language, such as sketches and paintings, in science education. To promote holistic learning, aesthetics should be combined with cognitive aspects in the science class (Girod et al. 2010).

Aesthetic experience is a prerequisite for children's meaning-making in educational settings. Intellectual, practical and emotional aspects are intertwined and equally important, enclosed by aesthetics (Dewey 1934/1980). In light of this holistic view, Dewey claimed that when an aesthetic experience comes into existence, relations and connections are summed up. Moreover, within an aesthetic experience, there is always anticipation concerning what is yet to come, which results in consummation and a closure. Dewey (1934/1980) further explained the dynamic rhythm of an experience in terms of a beginning, development and closure, all three vital in an aesthetic experience. Accordingly, continuity and change (Dewey 1934/1980) is always present in the rhythm.

Like Dewey (1934/1980), Kant (1790/2003) viewed aesthetics as belonging to people's ordinary lives as they deal with emotions related to experiences of pleasure/ 
displeasure and evaluation of taste in terms of beautiful/ugly. Accordingly, when children are creating meaning towards a purpose, it is possible to register an aesthetic experience through the use of positive and negative aesthetic judgements. Wickman (2017) elucidated Dewey's notion of experience, emphasising the dual aspects - the interconnection of the individual and the shared. It "is about living through an experience, of active participation in events and how the person is transformed through them and so becoming experienced" (Wickman 2017 p. 24). Moreover, experiences are shared and transacted with others, indicating the social dimension of people's lives and their surroundings. The term transaction is invented in contrast to interaction as the latter tends to treat humans and the milieu as separated and isolated entities. Adopting the economy metaphor, transaction, implies that buyers and sellers in the specific encounter are defined through their actions and not beforehand (Dewey and Bentley 1949/1991). In consonance, Dewey's (1938/1997) principle of continuity implies that earlier experiences are reconstructed and transformed in a new situation, having consequences for specific and future situations. From a pragmatic transactional standpoint, this dynamic movement is always related to a purpose and involves change (Dewey and Bentley 1949/1991). However, when Dewey (1899/1990) discussed students' degree of freedom in education, the emphasis was on the importance of giving students rich opportunities to formulate their own purposes. In light of this, students' agency increases, something Biesta and Tedder (2007) discussed in terms of people achieving agency in a situation rather than addressing agency as an individual capability, something that is possessed. Moreover, agency is viewed neither as an individual intrinsic nor as extraneous power, but as "engagement temporal-relational-contexts for action" (Biesta and Tedder 2007, p. 7).

\subsection{Imagination}

When humans are encountering complex issues, the process of imagination is regarded as the capacity for making new combinations. This is in line with Dewey's principle of continuity, "the conscious adjustment of the new and the old" (Dewey 1934/1980, p. 272). Garrison (1997) explained this further, maintaining that the process of imagination merges "ideas that can possibly reconstruct the situation" (p. 96), which is needed when confronting demanding and multi-layered problems. Such creative processes are about "dissolution of old objects" (Dewey 1925/1958, p. 220), and something new comes into existence. Likewise, Wittgenstein (1953/1996) emphasised the importance of attending to imagination, the vitality in seeing something in a new way. He gave an example of children playing using their imaginations:

...they say that a chest, for example, is a house; and thereupon it is interpreted as a house in every detail.

A piece of fancy is worked into it.

And does the child now see the chest as a house? "He quite forgets that it is a chest; for him it actually is a house". (p. 206, original emphasis)

When contemplating this example, sense and nonsense, fiction and fact, are all vital, indicating that they should be treated as a dynamic flux of equal importance in the process of imagination. When applying this theoretical elaboration to science education, Root-Bernstein (1996) argued that imagination is missing in current science curricula. Alongside scientific inquiry and learning facts and logic, the inclusion of imagination should be taken seriously.

Based on Dewey's pragmatic perspective, we argue that when the purpose is to provide innovative science education for young learners, imagination and aesthetic experience are of 
specific interest. Aesthetic experiences, in the sense of Dewey's (1934/1980) holistic theory, are important for learning cognitively, normatively and aesthetically in science class. Moreover, an aesthetic experience embraces students' possibility to participate or not in science class - a question of student identity and sense of belonging (Wickman 2006). Imagination enables children to reach beyond conventional ways of acting in science class, as well as to construct scientific problems and come up with new solutions. Taking children's imaginative flow (Csikszentmihalyi 1996) seriously challenges simplistic views of imagination as a superfluous and immature way of acting in science class.

\section{A Qualitative Analysis Approach}

Qualitative research makes a powerful contribution to research in science education. Maxwell (2004) argued for two key strengths of qualitative research. Firstly, it develops more sufficient and adequate explanations of educational processes and phenomena. To fulfil this need, context, not reduced to an external set of variables, and meaning, are put forward as having "explanatory significance" (Maxwell 2004, p. 7). Secondly, particular situations, rather than general patterns, contribute specifically with accuracy and detailed information which leads to deeper understanding. The emphasis is on scientific testability. According to our interpretation, the research process is transparent when using the research design repeatedly and modelling it further if necessary. In this article, we follow Maxwell's (2004) arguments. Accordingly, we specifically attend to contextual features such as children's art production, the place, space and material in use.

\subsection{Epistemology and Science Learning}

We depart from Dewey's pragmatic theory and the later works of Wittgenstein's philosophy (Wickman and Östman 2002) in order to closely examine meaning-making processes. Accordingly, the unit of analysis is situated actions (e.g. Harré and Gillett 1994; Wertsch 1995), elaborated in a pragmatic context as transactions (Dewey and Bentley 1949/1991). Learning then is seen as part of meaning-making, an active process where learning is tantamount to purposeful participation in specific activities resulting in learners gaining a broader repertoire of action (Öhman and Öhman 2013). Moreover, we regard talk as action, in line with Wittgenstein's (1953/1996) language games - when we talk, we are acting in relation to others (Wickman 2006). According to Wittgenstein (1953/1996), a language game implies that words get their meaning through their use in a specific situation. Participating in science class constitutes one such language game. Even art practice adopted in science class can be regarded as another language game, described in this article as art-language game.

In the work Remarks on colour, Wittgenstein (1950/1978) examined and expanded the idea of language games applying the same idea to chromatics, challenging the conception of colours as having intrinsic essence. By investigating an imagined tribe of colour-blind people with different experiences of colours, the colour concepts, often treated as logically uniformed, were questioned as according to Wittgenstein, philosophy rather ought to address problems in such way that it can be practically handled and solved (cf. Wittgenstein 1950/1978, § 11, p 15). Too often, we tend to be trapped in ontological issues ending up in dead ends with no practical consequences for our lives. Wittgenstein pushed the idea of language game to the edge by claiming that everybody learns the meaning of colour words in use differently, depending on 
the specific situation the interlocutors participate in. To summarise, colours and words of colours, like words in general, only get their meaning when used. Accordingly, we need to study a particular situation in order to understand the meaning of words and colours in use, including aesthetic judgements, and their consequences for learning (Harré and Gillett 1994; Wittgenstein 1953/1996, 1966).

\subsection{Practical Epistemological Analysis}

In order to carry out a qualitative analysis, we use practical epistemology analysis (PEA), an established analytical method, which is specifically developed for making deep and detailed analyses of ongoing meaning-making processes. Furthermore, PEA is developed in accordance with an epistemology that considers the social practice of what is regarded as knowledge in specific situations (Kelly et al. 2012). The analysis method has its roots in Dewey's pragmatic theory and the later works of Wittgenstein's philosophy (Wickman and Östman 2002).

PEA consists of four operational terms: stand fast, relation, gap and encounter (Wickman and Östman 2002). Stand fast implies that the interlocutors fully agree and do not need to pose any questions in the actual situation. However, what is standing fast is not static, but might change. When the interlocutors proceed, relations are continuously construed to what is standing fast and the meaning-making process expands and develops. The formation of a purpose directs the participants' activities, having consequences for the meaning-making process in which learning occurs (Dewey 1938/1997). Learning takes place when relations are construed bridging gaps, which then are said to be filled. Sometimes however, gaps cannot be filled, but are lingering, implying that learning might take another direction than intended or come to a halt. Relations are not just bridging gaps, but also distinctions in the ongoing flow of actions. Accordingly, discourses, such as science class practices, change in encounters between people and between people and the contextual features.

In this study, the terms relation and encounter are specifically used in the processoriented analysis. The reason for this selection is based on the empirical data in this study. No significant lingering gaps occurred regarding the science content, ecology. Throughout the process, the children focused on the task and the meaning-making process proceeded in a flux of events. Accordingly, the children's meaning-making concerns the process in which new relations continuously are construed to the ecology of animals and abiotic factors. The analytical concept encounter makes it possible to highlight all the contextual features the children utilised-which was vital for studying the consequences for children's learning and meaning-making. In this way, science meaning-making is regarded as an emergent, contingent act.

\section{Method}

Based on the pragmatic, action-oriented approach, elementary school children's explorations in an art and science-related practice are in focus. Teachers in three suburban schools were involved in a network that implemented a 1-year project which strove to create opportunities for children to make cooperative explorations and to construct their own science problems and questions. An important pedagogical foundation used 
throughout the project is the conviction that providing children with various aesthetic practices enhances and enriches meaning-making. Additionally, pedagogical documentation was used to capture the learning process in terms of seeing the situation in different ways as well as making a retrospective and prospective account of the situation (Elfström 2013).

In this study, we present results from one school, visited on three occasions over a period of four consecutive days. The school is located in a large suburb in Sweden, and the children participating in the study were between 6 and 7 years old (Swedish grade 1). The classroom consisted of 24 children and one teacher as well as a part-time assistant. In this specific study, we focus on two children and their teacher involved in ecology tasks. Focusing on only two children and the teacher's role makes it possible to closely examine the different phases in the process and its learning consequences. Data from this selected school consist of $5 \mathrm{~h}$ and $25 \mathrm{~min}$ of audio recordings and field notes of a group of six children and their teacher. In addition, photographs of the children's drawings were collected. The audio recordings were transcribed verbatim. No personally sensitive data were used, and the overall purpose and research questions do not exceed the limit of the children's personal integrity (Swedish Research Council 2018).

Based on Vecchi's (2010) educational influences on the significance of embracing an aesthetic-ethical practice when children create and co-construct meaning, the aesthetics have been taken into consideration when scientific phenomena such as spiders' morphology and ecology and hunting and predation are explored. To be more specific, art practices, in which young learners can make drawings and sketches using various artistic material, were investigated.

The children, the teacher and the assistant had been exploring spiders and creating different ecological systems throughout the project. In parallel, the teacher encouraged the children to continuously draw and talk about what they observed throughout the science project. Following the audio recordings, specific moments were located in the data and the art practices in which the children cooperatively explored and invented science-related problems important to them. First, the specific material was viewed as a whole in order to find sequences and critical incidents, in this case when children explicitly explored ecology relations. Secondly, we continued by coding those moments with a defined beginning and ending (Flanagan 1954). This is in accordance with Dewey's (1934/1980) notion of an aesthetic experience in terms of a beginning, development and closure - all vital in the learning process. Thirdly, a selection was made through a careful reviewing, first separately by each author and then jointly deciding what to use when elaborating on the overall purpose. Rooted in a pragmatic theory, learning is discernible in children's actions, such as speech and drawing, making it possible to break down the purpose into sequences. These sequences, presented as vignettes, were transcribed in detail and selected as representative of the project as a whole. Accordingly, they are dealt with as illustrative examples of the different roles and consequences of art practice in elementary school science. To achieve a richer description (Geertz 1994; Ponterotto 2006) and to get a more thorough and detailed analysis in those particular moments, we included and paid attention to children's drawings. In the fourth and final stage, we analysed how new relations were construed within the children's ongoing communications and transactions.

In this study, four research vignettes and accompanying drawings are scrutinised and discussed. The four vignettes identify how young children's previous experiences, their 
paintings, as well as the very creation of drawings, were significant for science meaningmaking. In the analysis, we also paid specific attention to when the children anticipated what is to come and brought enthusiasm to the situation, as well as to the purposes (problems) they created, reconstructed and transformed during the process.

\section{Findings}

\subsection{Vignette 1. A Spider, a Net and the X-ray Vision—Prey's Vulnerability}

The children were involved in a science project during one semester, observing and exploring various species of spider belonging to different families, for example, weavers and jumping spiders. During the project, the children watched documentary films about spiders and systematically observed live spiders, spider webs and photographs of spiders while simultaneously drawing them. The images were made using a variety of media, from pen-and-ink drawings to watercolour paintings. The purpose was for the children to grasp the characteristics of spiders and notice ecological relations to other species and the environment. In this situation, Nadi and Bahar revisit their drawing (Fig. 1). The teacher stands a little behind, listening.

Bahar started speaking: "Here I did such a good thread. That spider makes such thin threads. It's not silk in such a thread. A super long... and thin too, it comes out from...the red bump there [points at the red spot at the hindquarter of the big spider]. A large-web... spiders make them, so fine, in them they catch...just small animals. A green fly will probably be caught in it later." Nadi nodded and continued: "Insect animals get stuck. No, no, no! I can't get out. It gets too tangled [in a light and loud voice]. The spider can see everything in all directions [points at the spider]. It might be X-ray vision?" Bahar continued: "Yeah, first the X-ray vision then...then jumps on [inaudible] and sucks out life!" Nadi made a face when saying: "Poor that fly, which then is whirled in. It's probably the most horrible when it turns out in this way...super-horrible. And it can happen!"

In this transaction, encountering the drawing, Bahar construed several relations in terms of "good thread", "thin threads", "not silk" and "super long" to the spider's web. Accordingly, in the beginning of the process, she focused on the specific qualities of the spider's thread. Next,

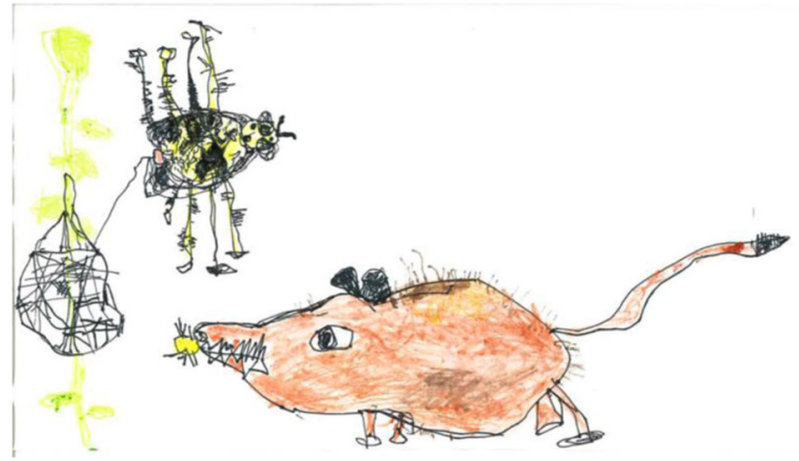

Fig. 1 The children's drawing including the spider, spider web and a shrew 
Bahar expanded her description with the relation "comes out from" to "it", "the red bump", where the thread is produced. By doing so, she located the spot at which the thread is emerging.

The children's meaning-making process continued as Bahar construed the relation "fine large web" to the spider "making" them. The observation of the drawn spider expanded and deepened when Bahar construed the relation "small animals" being caught in the spider web. Moreover, the prey, "a green fly", was verbally introduced, but was not visible in the drawing. In this part of the process, the children started to explore the spider's predation. Through this process, their anticipation and desire were revealed, for example, in Nadi's expression: "It's probably the most horrible when it turns out in this way...super-horrible. And it can happen!" Next, the function of the web for predation was construed through the relations: insects will "get stuck" in the spider's web, which is "tangled" and hard to escape from. In this situation, the web, the capture and the entanglement gain meaning.

In addition, an ethical implication concerning the life of a captured fly is shown in Nadi's cry: "No, no, no! I can't get out", and the vulnerable situation of the fly was emphasised. Nadi proceeded to talk about the spiders' ability to "see in all directions". By doing so, spiders' morphology was reactualised and transformed, resulting in a question about spiders having "X-ray vision", which Bahar immediately agreed with. In this way, spiders' behaviour when capturing prey was elaborated as spiders use their "X-ray vision" before fulfilling the predatory action.

The ethical concern about the fly was further stressed and anticipated by the negative aesthetic relations "poor", "horrible" and "super-horrible" and the life of the fly drawing to an end. Care and concern for small prey developed within the process and merged with aesthetic experiences as the spider's hunt was "horrible". Bahar intensified the situation further when he construed the relation "sucks out life" to the actual predation, and Nadi confirmed that it "can happen". Accordingly, when the girls imagined this scenario, the significance of their anticipation, "what actually might happen", was obvious. Consequently, the children set the stage for further conceivable explorations of hunting acts.

The art practice which was elaborated, and the children's encountering and verbally revisiting the drawing, had consequences as it promoted their communication and science learning. During this part of the process, science content knowledge emerged; for example, spiders' characteristics, predation, hunting skills and ecology were elaborated. Spiders' morphology and specific characteristics were shown to be important when developing and anticipating the "horrifying" hunting scenario. The science content, such as learning about arachnids, was also exposed in the drawing. Notice the eight hairy legs and the thread connected to the spinneret and the net (Fig. 1). Consequently, the significance of art practice - drawing and talking — enhanced children's learning and meaning-making in science class. However, in the centre of the drawing, a large shrew dominates the foreground, although the children had not yet commented on.

\subsection{Vignette 2. The Hunting Shrew-Predation}

The following day, the activity continued with the girls talking about the drawing of the spider, and after a while, the shrew was brought to attention. Once again, the teacher was standing beside the children.

Nadi started the conversation: "The spider then has to make more spider web again 'cause it's broken and also ugly. The wings [of the fly] have destroyed the web. Work, work, work. At 
the computer we saw...the thread was something with proteins, what's that? That movie was super scary!" Bahar nods and says with a weak voice: "I didn't dare to look, 'cause then... there came a dreadful... a shrew and he was angry....and so starving...just jumped on that tiny spider. We did that [points at the drawing]." The teacher approaches the children slowly and said: "Yes, just like that, how well you remember. What a nasty hunting we saw then."

In this transaction, Nadi construed the relations "broken" and "ugly" to the spider web, implying that the spider got more demanding work to do. She then reactualised her previous experience of a documentary film construing the relation "threads" to "proteins". The question concerning what the thread is made of, "proteins", was however not answered. Instead, the discussion took a new direction, and yet another hunting scenario was introduced, now involving the shrew (Fig. 1). The negative aesthetic judgements "super scary", "dreadful" and "angry", with an aesthetic negative undertone "so starving", were construed to the shrew during the first part of the hunting act. Again, the children were engaged in what was to occur and learned aesthetically about the "starving", hunting shrew. However, the negative aesthetic experience did not hinder the children from proceeding with the activity. On the contrary, they specifically anticipated the arrangement of prey and predator, and a sense of horror and delight occurred. The predation was intensified when the relation "jumped on" was construed to the activity of the shrew, who was eating "tiny spiders", also exposed in the drawing: the shrew had just caught a spider, which is hanging out of its mouth (Fig. 1). Again, there was an ethical concern regarding the captured tiny spiders, which presumably have little chance of defending themselves. The teacher positively confirmed the children's recapitulation of the event.

In this situation, the children's interactions between themselves, the teacher and the drawing resulted in the emergence of a science question. The challenging question on the specific chemical compounds of spider threads, "proteins", was not further elaborated on-a complex issue possibly hard for the teacher to handle. The art practice-drawing - again afforded the children opportunity to explore and learn about the spider's role in an ecosystem as well as to design new predation scenarios, or in other words explore the dynamics of predator-prey relations, expressed in negative aesthetic judgements. Further, the children's experiences of a documentary film gained specific meaning as it fertilised their anticipation and engagement. In the two first vignettes, the dynamic art event comprised several significant scientific features. Consequently, the event as a whole expanded and the children's learning and meaning-making in science were ameliorated and deepened.

\subsection{Vignette 3. A Spider-Thread Machine-Imagination}

The teacher encourages the children to continue their discussion on the spider and directs a question to another drawing made by the children (Fig. 2). The drawing, a result of the children's own interest, is rich in detail, showing specific parts and functions. The teacher calls for more explanations about a "bun", illustrated in the drawing as well as verbally discussed by the children.

The teacher asked: "Can you tell me about how that bun, the spinneret [Sw. spinnvårta]... how it becomes a thread. Do you have any ideas about that?" Nadi utterred in a soft voice: "Yes, we did a bit...like this. Can you see that bun there [she points at the drawing]." The teacher nodded to Nadi and asked: "Is that the spinneret?" Nadi 


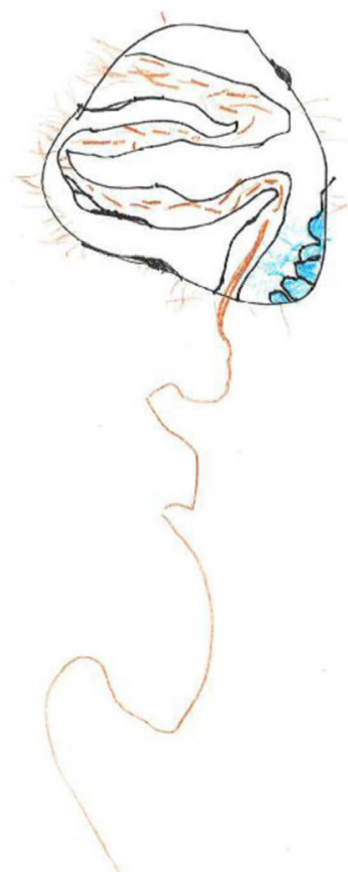

Fig. 2 The components of the spider-thread machine: blue slime paste, short hair, squiggly way and long thread

continued: "It's not a wart [Sw.vårta]. That's a...spider-thread-machine making longthread." Bahar joined: "We also made short hair on that bun, can you see that? and the teacher utters: Yeah." Bahar continued: "It [inaudible] the hair can then also come into the bun and it's a machine. Into that squiggly way there comes very much hair. It's such short hair going in there and then, then come the blue bubbles." Nadi smiled and said: "They make gas." Bahar smiled as well and utterred: "No, not gas whereupon." Nadi interposed: "No?" Bahar sweeped her finger across the drawing and said: "Gas...That gas, that gas is glue." Nadi rapidly continues: "No, not quite. It's slime. Yeah, slime! It pastes the hair. Yes, it pastes together and becomes a long-thread." Bahar immediately responded: "Then it becomes a long-thread and then it [the spider] can spin fine nets."

Based on the children's conversation and encounter with the drawing, the teacher construed the relations "spinneret" and "thread" to the "bun", calling for more explanations on how the "thread" is produced. Nadi pointed to the "bun", and the teacher continued asking if the "bun" was synonymous with the "spinneret", which was immediately rejected by Nadi. Instead, Nadi construed the relation "not a wart" to "it", the "bun", and in addition, the imaginative relations "spider-thread machine" and "making long thread" were construed. In this part of the process, Bahar construed the relation "short hairs" to the "bun", confirmed by the teacher. Accordingly, the "bun" was fully intelligible to the participants. Furthermore, Bahar proceeded talking about the "hair" coming into the spider-thread machine. Again, imagination is intertwined when explaining the function of the extraordinary machine. Bahar continued explaining where the hair was transported in the bun, construing the relation "squiggly way" to "hair". She deepened her explanation while construing the relation "short hair" to "blue bubbles". 
Other relations such as "gas", "glue" and "slime" were introduced, and during the final stage, the children further imagined how the spider-thread machine functioned: the "slime pastes" the "short hair" and in this way a "long thread" is made. In this aesthetic event, a winding montage of colour was visualised in the drawing (Fig. 2) and several imaginative experiences were shown to be fruitful when creating something new in scientific practice.

The teacher had been quiet for a while, taking notes, attentive to the children's explorative talk. Now, the teacher took a more active part in the process, bended over, pointed at the drawing and slowly recapitulates: "Well, now I understand precisely. The machine makes a long-thread from the short, the short hair placed on, outside...the bun." Bahar eagerly agreed: "Mm. Can you see the gas that is pasting, can you see?", and she continues by explaining: "We figured that out when we were drawing. There is a need for paste gas. We figured that out when drawing." The teacher confirmed: "How exciting, when you're drawing...Different colours. Was it then you found out how it should be?" Bahar intensified the tempo: "Yeah, Nadi did such a nice colour, blue... She did that when the squiggly ways with all hair were ready. Then she did blue, such fluff...nice..." She further increased the tempo when saying: "and then we found out! The blue shall be the paste!" Nadi slowly said: "Mm, such blue" and emphasised slime paste. Nadi further explained: "We draw and also talk. We talk too! The machine makes a spider-thread on such a ...such a..." Bahar waited for Nadi who finally said: "Done!" The teacher asked: "Well, you didn't figure it out beforehand? Is that what you mean? You found out that when drawing? When drawing you found out new details and how it should work inside the spinneret, didn't you? I mean inside the bun."

Bahar agrees with the teacher's recapitulation and eagerly asked if the teacher noticed the gas "pasting". Then, Bahar explained that when creating the actual drawing, they "figured out" the "need for paste gas". Through the teacher's aesthetic judgement, "exciting", the drawing-in-the-making is still in focus. Relations were now construed to Nadi's choice of blue colour, such as "nice" and "fluff". However, Bahar clarified the specific order of the procedure when the creation of the machine takes place. At first, imagination was involved when "squiggly ways" with "all hair" in the spinneret were sketched out. Second, the blue colour was added, fertilising the imagination further. Third, Nadi agreed, and yet another imaginative relation to "paste" in terms of "slime paste" was construed. Fourth, the choice of blue colour gained specific meaning and enriched their imaginative construction even further when pasting short hair into longer - a vital part of the spider-thread machine (Fig. 2). Obviously, talking and drawing were deeply intertwined in the imaginative co-construction of the spider-thread machine as uttered by Nadi's relations "draw and talk" to the actual activity. The process reached fulfilment, and all along anticipation was involved as the narrative becomes intensified and increases in tempo. The invention was finally completed as Nadi came to a closure, "Done!". The teacher once again recapitulated the procedure highlighting the instantaneous act of drawing.

In an instant, when using a particular blue colour, the invention of a vital component, "slime paste", was imagined. The actual drawing-in-the-making engaged, enticed and made it possible for the children to conduct the creation of a spider-thread machine while imagination was involved along the way. In this encounter, the children designed and explored spiders through art practice, simultaneously deepening their knowledge and reach beyond conventional ways of acting in science class. In this manner, a science problem under construction emerged. Accordingly, art practice in science class held the potential for fabricating new ideas through communication and visual language (Fig. 2). 


\subsection{Vignette 4. Camouflage and Protection-Avoidance}

Two days later, Nadi and Bahar were back at the working table. Yet, another line of inquiry arose as the children started to talk about animal protection, specifically bacteria and insects. Throughout the project, spiders were described in the web of ecology, also mentioned in the beginning of the following process. The teacher was present and listening.

Bahar introduced the topic by highlighting: "It's lucky that the little cute ones [spiders] can hide... under such old bark or under rocks." The teacher asked: "Are there any other suitable shelters for the small animals? Would you like to draw some more, different shelters?" Bahar replied: "Noo, don't draw now, but I can tell...they can stay in long grass. Really invisible! The really tiny animals, they can also hide inside...eagle-feathers." Nadi asked: "What, eagle, what?" whereas Bahar continued: "The teeny tiny bacteria they really can, you see...they can stay in feathers". Nadi said: "Well, how strange [the girls fetch colours and start drawing]." Nadi continued while sketching: "Or animals can, can creep deep down into moss 'cause it's nice and cosy." Bahar nodded and Nadi continued: "Insects make tunnels in the soil, very hard, down in soil, so far down. There they lie resting and then it's nice. At last, they can rest! [inaudible]" Bahar said: "The tiny, for sure, they have to find out...new hiding places or they will get eaten. Some animals have camouflage, that's good... a green fat-caterpillar is invisible if it stays on a leaf. That's really awesome! No shrew can see such a green-leaf-caterpillar."

In this transaction, Bahar construed positive aesthetic relations, such as "lucky" and "cute" to spiders, implying that she anticipated what was going to happen. Moreover, relations were construed to "hide" in terms of "old bark" and "under rocks". Accordingly, Bahar made meaning concerning spiders' potential escape strategies to elude predators. By proposing that the children drew "different protections", the teacher attempted to develop the discussion; however, this was rejected by Bahar. Instead, Bahar orally chose to construe the relation "long grass" to "protection", where spiders can hide. She proceeded by construing yet more relations to "protection", such as "really tiny animals" and "eagle feathers". In doing so, she created another escaping and hiding scenario in accordance with the teacher's science question. However, Nadi was puzzled, and Bahar proceeded explaining more thoroughly by construing the relation "teeny tiny bacteria" to "really tiny animal", who can hide in "eagle feathers". Still, Nadi was not fully convinced, shown in the relation "strange" to Bahar's explanation. During the drawing practice though, Nadi now broadened the exploration of prey escaping, construing the relations "creep" and "into moss" to "animals". In this way, another hiding scenario was examined, which was fully intelligible to Bahar. Then, Nadi construed relations to "insects" in terms of "tunnels" and "soil", probably yet another hiding scenario. Bahar continued construing relations, such as "hiding places" and "get eaten" to "tiny" insects. Doing so, the contingent escaping aspects of hunting acts were elaborated. Introducing another potential escaping scenario, Bahar construed the relation "camouflage" to "animals", by the example a "green fat-caterpillar", which can escape from predators when sitting on a green leaf (Fig. 3).

In this transaction, the children excavated and explored animals' multiple escape strategies, enhanced by the teacher's two prospective science-oriented questions (Fig. 4).

In this way, the children deepened their learning about prey's different defence strategies and adaptation to local conditions. The caterpillar, for example, mimics the leaf when deceiving predators. Moreover, in this part of the process, the children were ethically involved, shown in positive aesthetic relations in terms of "cute", "teeny tiny", "nice and cosy" to various prey, comparable to the captured fly in the shrew's mouth (Fig. 1). Consequently, the children's concerns for and attachments to prey were anticipated throughout the process. 


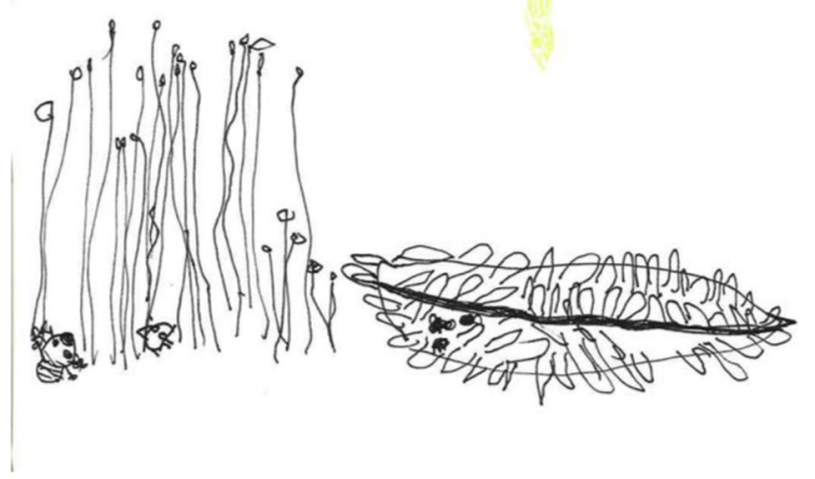

Fig. 3 The various prey-hiding strategies

The art practice was incorporated subsequently - talking and drawing-in-the-making were shown to be complementary, facilitating and deepening the children's meaningmaking process in science class. In the children's aesthetic process, the anticipation of predator-prey relations recurred when they focused on camouflage and protection. To sum up, during the encounters with each other, the teacher and the science content, the children extended the ecological web by delving more deeply into prey's various defence strategies. Taking into consideration the children's meaning-making process and the drawing outcome, the complex phenomenon "camouflage" was profoundly examined in terms of a representation (Fig. 3) and as a cognitive exploration of the phenomenon. Retrospectively, involving aesthetic processes in science class was continuous with learning the science content. Long-term ecological relations were construed through

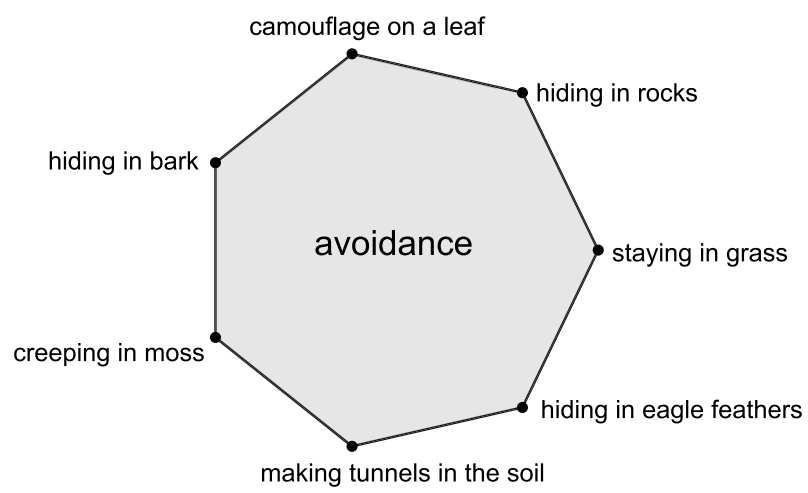

Fig. 4 The children's recognised prey-escape strategies 
the process as a whole in this vignette, exemplified by the recurrence of the forceful predator - the shrew - at the very end of the process. In light of this encounter, the first notion of an interactive ecological trait appeared: the predator shapes the prey's adaptations for escape. However, the shrew's own adaptations for pursuit and capture, shaped by the various prey, were not visible in this process.

\section{Discussion}

Based on Dewey's (1934/1980, 1925/1958) pragmatic works on aesthetics, adopting art practice in science class was empirically shown to be of utmost significance. In alignment with Dewey's (1934/1980, p. 286) claim that "art is the most effective mode of communication that exists", children's art practice and discussions about animals resulted in several learning consequences in science class.

First, the intertwinement of art practice and the children's ongoing conversations cultivated their observations and explorations regarding science content (Gurnon et al. 2013), such as morphology, hunting skills, prey-predator arrangements and camouflage scenarios.

Second, based on this study, science learning and art-in-the-making were found to have common characteristics, such as doing meticulous observations and making predictions as presented by Gurnon et al. (2013) interdisciplinary approach. This study also shows how art and science merged in several ways, for example, in the children's fascination with the spiders' hairy legs as visualised in the drawing (Fig. 1). More specifically, science content-an ecological web-grew and expanded into seven different prey-escape strategies (Fig. 4). Noticeably, these strategies emerged as a consequence when science activities were conducted in accordance with science learning "as an aesthetic event" (Olsson et al. 2016, p. 725).

Third, besides, the predators' role in the children's knowledge production of ecology was due to the teacher's being attentive to all phases in the science learning process, for example, empirically shown in the return of the shrew at the end (Vignette 4). This is in accordance with Dewey's (1934/1980) pragmatic theory of learning, which emphasises the dynamic rhythm of experience that includes a beginning, development and closure, all three vital in an aesthetic experience. However, continuity and change are always present in the rhythm, but are not always easy to target analytically. For example, in the beginning, the shrew loomed large in the drawing but was not present in the discussion (Fig. 1). During the development of the process however, the children verbally anticipated the shrew and its function in the ecological web. When the process reached for a fulfilment and closure, the recurrence of the shrew suddenly became significant to the learning about prey-predator arrangements.

Fourth, simultaneously, the science content "camouflage" was explored, wherein nuances of green colours played a vital role suggested as a specific "colour game" (cf. Wittgenstein 1950/1978, Fig. 3). In this context, the use of colours was a communicative resource in alignment with Wittgenstein's language game (Wittgenstein 1950/1978). The green colours as well as the blue entering the spider-thread machine implied that both materials (colours) and children's engagement are intertwined when communicating and learning science. Accordingly, the children learned cognitively and aesthetically about animal ecology and consequently broadened their "science-art-language game".

Fifth, adopting art in science education has the potential to promote children's fabrication of new and imaginative science-related ideas and problems as discussed by Gurnon et al. (2013) and Katz-Buonincontro (2018). As shown in this study, when the children were 
engaged in constructing a highly complex science problem of concern, such as how the spinneret functions, art practice and imagination enhanced the science learning process (Caiman and Lundegård 2018; Root-Bernstein 2015). In accordance with Garrison and Dewey's notion of imagination, the act of "dissolution of old objects" (Dewey 1925/1958, p. 220) that is blending "ideas that can possibly reconstruct the situation" (Garrison 1997, p. 96) was revealed. Children's earlier experiences of, for example, inquiring into living spiders were reconstructed and transformed having consequences in the actual situation. In comparison to Bacon and Sylvester's (1975/2016) detailed conversation about how art processes develop, Bacon's brushes occasionally took over the art process, which indicates the necessity of simultaneously embracing contingency and the accidental. In light of this, the transaction where the children encountered the blue colour, a selective choice is made instantly (Vignette 3). The complex spider-thread machine gradually and miraculously started to function. Accordingly, the children in this study operated in a cross-border manner, pushing the limit of science and art practice, comparable to scholars claiming that learning science in the early years can be viewed as a hands-on and emergent act (Caiman 2015; Larsson 2013; Siry and Max 2013; Siry et al. 2012). At first, the children's actions might seem irrelevant or even naive. However, on closer scrutiny, imagination, such as the instantaneous construction of the spider-thread machine, was shown to be significant for how the children proceeded to explore the life of spiders. Imagination also played a role when the children constructed ecological visions, such as the shrew's hunting and the prey's hiding strategies. To sum up, taking imagination into serious consideration in science class is an educational prerequisite as imagination supports young learners in the very creation of a "problem under construction" (Olsson 2013) as well as supporting them to install themselves within the scope of potentiality-something new might come into existence.

Sixth, drawing on Dewey's discussion of the degree of freedom in education, the children in the present study were encouraged to invent their purposes, although within the frame of a carefully prepared scientific context. In this way, the science teaching arrangement facilitated children to stay within the scientific domain intended by the teacher by practicing a thorough, radical listening (Siry and Brendel 2016). The benefit of supporting young children's agency, elaborated as a contingent situated act, or "context for actions" (Biesta and Tedder 2007), displaced the teacher's authority while children remained in charge of designing the whole process throughout (Caiman and Lundegård 2014; Siry et al. 2012). When children were in charge of their learning, there were no dividing lines between fiction and fact or sense and nonsense, and consequently, new logics emerged in the process. In light of this, teaching can be viewed as a delicate balancing act when adopting art in science class. In this study, the teacher practiced radical listening (Siry and Brendel 2016) to support children's anticipation and their distinctions and choices in the course of their actions, thereby promoting the development of children's agency (Vignette 1-4). As the teacher participated on the periphery of the event, taking notes, listening and sparsely posing prospective and retrospective questions, the children were allowed to design and invent the learning process (cf. Vecchi 2010). On the other hand, teaching expertise sometimes implies the necessity for teachers to continuously update their science content knowledge as children's scientific questions often become deep and extensive. As an example, when children explored the role of proteins in the production of spider threads, the route of scientific meaning-making did not fully progress (Vignette 2). Accordingly, teacher's contribution of scientific knowledge is significant for deepening children's learning.

Seventh, during art practice, it was possible to track the children's aesthetic experiences through their use of positive and negative aesthetic judgements. Aesthetic experiences were 
shown to comprise cognitive, normative, emotional and aesthetical aspects (Jakobson 2008; Jakobson and Wickman 2008b). Furthermore, this study reveals that the children developed a multiplicity of attachments and ethical concerns towards the animals, emanating from their aesthetic experiences during the process (Vignette 1-2). Those concerns were shown throughout, signifying the value of taking children's aesthetic utterances seriously (Jakobson and Wickman 2008b). Children's ethical concerns about animals' welfare and the thrill of predators hunting prey guided the learning events, elaborated as a scientific enterprise.

Finally, in this study, we have striven to empirically implement Maxwell's (2004) call for strengthening qualitative research specifically regarding explanatory claims to learning processes in education. Hence, in order to grasp the complexity of young children learning science, this study focused on context, meaning and particular situations. In doing so, the explanatory significance was seen in the children's aesthetic experiences through art and speech, in the imaginative flow (Csikszentmihalyi 1996), in the teacher's radical listening as well as in the occasionally raised scientific questions. Furthermore, we agree with scholars who have argued that qualitative research contributes to accuracy, detailed information and analytical precision which results in a deeper understanding of learning and meaning-making in science class (Maxwell 2004; Wickman 2017). Moreover, PEA and its operational concepts are useful for replicating and testing qualitative results and analysis and add real value to the examination of scientific learning and meaning-making in an epistemic culture (Kelly et al. 2012).

To sum up, the purpose of this study was to examine science-in-the-making and art-in-themaking as a whole and the consequences for children's learning in science class. Being attentive to children's previous experiences, imagination and the ethical concerns they developed through the process was important in the meaning-making process. Likewise, cognitive learning, emotions, aesthetics and practical artwork are all significant parts of an aesthetic experience elaborated as growth, resulting in children broadening their scientific and aesthetic repertoire (Dewey 1934/1980, 1938/1997). The overall contribution of this study is that it shows the significance of intertwining art and science education. More specifically, the study reveals in what different ways art- and science-in-the-making enhance children's possibilities to broaden and deepen their meaningmaking in science class - a contingent process, yet with explanatory epistemological claims.

\section{Compliance with Ethical Standards}

Conflict of Interest The authors declare that they have no conflict of interest.

OpenAccessThis article is distributed under the terms of the Creative Commons Attribution 4.0 International License (http://creativecommons.org/licenses/by/4.0/), which permits unrestricted use, distribution, and reproduction in any medium, provided you give appropriate credit to the original author(s) and the source, provide a link to the Creative Commons license, and indicate if changes were made.

Publisher's Note Springer Nature remains neutral with regard to jurisdictional claims in published maps and institutional affiliations.

\section{References}

Barad, K. (2007). Meeting the universe halfway. Quantum physics and the entanglement or matter and meaning. London: Duke University Press.

Bateson, G. (1971). Steps to an ecology of mind. Chicago: The University of Chicago Press. 
Biesta, G., \& Tedder, M. (2007). Agency and learning in the lifecourse: towards an ecological perspective. Studies in Education of Adults, 39(2), 132-149.

Bronson Alcott, A. (1836/1991). How like an angel came I down. In A. O. Howell (Ed.), Conversations with children on gospels. New York: Lindisfarne books.

Caiman, C. (2015). Naturvetenskap i tillblivelse-barns meningsskapande kring biologisk mångfald och en hållbar framtid. Stockholm: Stockholm University.

Caiman, C., \& Lundegård, I. (2014). Pre-school children's agency in learning for sustainable development. Environmental Education Research, 20(4), 437-459.

Caiman, C., \& Lundegård, I. (2018). Young children's imagination in science education and education for sustainability. Cultural Studies of Science Education, 13(3), 687-705.

Csikszentmihalyi, M. (1996). Creativity: flow and the psychology of discovery and invention (1st ed.). New York: Harper Collins.

Deleuze, G. (1981/2013). Francis bacon: the logic of sensation. London: Bloomsbury Academic.

Dewey, J. (1899/1990). The school and society. The child and the curriculum. London: The University of Chicago Press Ltd.

Dewey, J. (1925/1958). Experience and nature. New York: Touchstone.

Dewey, J. (1934/1980). Art as experience. New York: Perigee Books, Berkely Publishing Group.

Dewey, J. (1938/1997). Experience \& education. New York: Dover.

Dewey, J., \& Bentley, A. F. (1949/1991). Knowing and the known. In I. J. B. Boydson (Ed.), The later works, 1925-1953 (Vol. 16: 1949-1952, pp. 1-294). Carbondale: Southern Illinois University press.

Dove, J. E., Everett, L. A., \& Preece, P. F. W. (1999). Exploring a hydrological concept through children's drawings. International Journal of Science Education, 21, 485-497.

Elfström, I. (2013). Uppföljning och utvärdering för förändring: Pedagogisk dokumentation som grund för kontinuerlig verksamhetsutveckling och systematiskt kvalitetsarbete i förskolan. (Assessment and evaluation for change: Pedagogical documentation as foundation for continuous development of practice and systematic quality work in early childhood education). Stockholm: Stockholm University.

Flanagan, J. C. (1954). The critical incident technique. Psychological Bulletin, 51(4), 327-358.

Garoian, C. R. (2013). In the event that art occurs. Visual Arts Research, 39(1), 18-34.

Garrison, J. (1997). Dewey and Eros. Wisdom and desire in the art of teaching. New York: Teachers College Press.

Geertz, C. (1994). Thick description: toward an interpretive theory of culture. In M. Martin \& L. C. McIntyre (Eds.), Readings in the philosophy of social science (pp. 213-231). Cambridge: MIT Press.

Girod, M., Rau, C., \& Schepige, A. (2003). Appreciating the beauty of science ideas: Teaching for aesthetic understanding. Science Education, 87, 574-587.

Girod, M., Twyman, T., \& Wojcikiewicz, S. (2010). Teaching and learning science for transformative, aesthetic experience. Journal of Science Teacher Education, 21, 802-824.

Goulart, M. I. M., \& Roth, W. M. (2010). Engaging young children in collective curriculum design. Cultural Studies of Science Education, 5, 533-562.

Gurnon, D., Voss-Andreae, J., \& Stanley, J. (2013). Integrating art and science in undergraduate education. Plos Biology. https://doi.org/10.1371/journal.pbio.1001491.

Harré, R., \& Gillett, G. (1994). The discursive mind. London: Sage Publications, Inc..

Hulland, C., \& Munby, H. (1994). Science, stories, and sense-making: a comparison of qualitative data from a wetlands unit. Science Education, 78, 117-136.

Jakobson, B. (2008). Learning science through aesthetic experience in elementary school. In Aesthetic judgement, metaphor and art. Stockholm: Stockholm University.

Jakobson, B., \& Wickman, P.-O. (2008a). Art in science class vs science in art class: a study in elementary school. Education \& Didactique, 2(3), 141-157.

Jakobson, B., \& Wickman, P.-O. (2008b). The roles of aesthetic experience in elementary school science. Research in Science Education, 38(1), 45-65.

Jakobson, B., \& Wickman, P.-O. (2015). What difference does art make in science? A comparative study of meaning-making at elementary school. Interchange, 46, 323-343.

Kant, I. (1790/2003). Kritik av omdömeskraften (Critique of judgment). Stockholm: Bokförlaget Thales.

Katz-Buonincontro, J. (2018). Gathering STE(a)M: policy, curricular, and programmatic developments in artsbased science, technology, engineering, and mathematics education. Introduction to the special issue of arts education policy review: STEAM focus. Arts Education Policy Review, 119(2), 73-76.

Kelly, G. J., McDonald, S., \& Wickman, P.-O. (2012). Science learning and epistemology. In K. Tobin, B. Frazer, \& C. McRobbie (Eds.), Second international handbook of science education (pp. 281-291). Dordrecht: Springer.

Kouvou, O. (2016). Drawing with children: an experiment in assisted creativity. The International Journal of Art \& Design Education, 35(2), 275-290. 
Larsson, J. (2013). Contextual and conceptual intersubjectivity and opportunities for emergent science knowledge about sound. International Journal of Early Childhood, 45(1), 101-122.

Latour. (1999). Pandora's hope. Essays on the reality of science studies. Cambridge: Harward University Press. Linde, U. (1960). Spejare (visionary). Göteborg: Bonnier.

Linde, U. (1962). Lennart Rodhe. Stockholm: Bonniers små konstböcker.

Lundin, M., \& Jakobson, B. (2014). Situated meaning-making of the human body: a study of elementary school children's reasons in two different activities. Cultural Studies of Science Education, 9(1), 173-191.

Maxwell, J. A. (2004). Causal explanation, qualitative research and scientific inquiry in education. American Educational Research Association, 33(2), 3-11.

Öhman, J., \& Öhman, M. (2013). Participatory approach in practice: an analysis of student discussions about climate change. Environmental Education Research, 19(3), 324-341.

Olsson, L. M. (2013). Taking children's questions seriously. The need for creative thought. Global Studies of Childhood, 3, 230-253.

Olsson, L. M., Dahlberg, G., \& Theorell, E. (2016). Displacing identity — placing aesthetics: early childhood literacy in a globalized world. Discourse: Studies in the Cultural Politics of Education, 37(5), 1-22.

Pickering, A. (1995). The mangle of practice. Time, agency, and science. London: The University of Chicago Press.

Poldberg, M. M., Trainin, G., \& Andrzejczak, N. (2013). Rocking your writing program: Integration of visual art, language arts, \& science. Journal for learning through the arts, 9(1), 3-20.

Ponterotto, J. G. (2006). Brief note on the origins, evolution, and meaning of the qualitative research concept 'thick description'. Qualitative Report, 11, 538-549.

Prain, V., Tytler, R., \& Peterson, S. (2009). Multiple representation in learning about evaporation. International Journal of Science Education, 31(6), 787-808.

Reiss, M. J., \& Tunnicliffe, S. D. (2001). Students' understanding of human organs and organ systems. Research in Science Education, 31, 383-399.

Reiss, M. J., Tunnicliffe, S. D., Andersen, A., Bartoszeck, A., et al. (2002). An international study of young people's drawings of what is inside themselves. Journal of Biological Education, 36, 58-64.

Root-Bernstein, R. S. (1991). Teaching abstracting in an integrated art and science curriculum. Roeper Review, $13,85-90$.

Root-Bernstein, R. S. (1996). The sciences and art share a common creative aesthetic. In A. I. Tauber (Ed.), The elusive synthesis: Aesthetics and science (pp. 49-82). Dordrecht: Kluwer Academic Publishers.

Root-Bernstein, R. (2015). Arts and crafts as adjuncts to STEM education to foster creativity in gifted and talented students. Asia Pacific Education Review, 16, 203-212.

Siry, C., \& Brendel, M. (2016). The inseparable role of emotions in the teaching and learning of primary school science. Cultural Studies of Science Education, 11, 803-815.

Siry, C., \& Kremer, I. (2011). Children explain the rainbow: using young children's ideas to guide science curricula. Journal of Science Education and Technology, 20, 643-655.

Siry, C., \& Max, C. (2013). The collective construction of a science unit: framing curricula as emergent from kindergarteners' wonderings. Science Education, 97(6), 878-902.

Siry, C., Ziegler, G., \& Max, C. (2012). "Doing science" through discourse-in-interaction: young children's science investigations at early childhood level. Science Education, 96, 311-366.

Swedish Research Council (2018). Research ethics. Retrieved the 11 th of April 2108 from http://www.codex.vr. se/texts/HSFR.pdf

Sylvester, D. (1975/2016). Interviews with Francis bacon. London: Thames \& Hudson Ltd.

Teixera, F. M. (2000). What happens to the food we eat? Children's conceptions of the structure and function of the digestive system. International Journal of Science Education, 22, 507-520.

Vecchi, V. (2010). Art and creativity in Reggio Emilia: exploring the role and potential of ateliers in early childhood education. London: Routledge.

Watts, M. (2001). Science and poetry: passion v. prescription in school science? International Journal of Science Education, 23, 197-208.

Weigand, G. (1985). From science into art. Art Education, 6, 18-21.

Welsh, W. (1997). Undoing aesthetics. London: SAGE Publications Ltd.

Wertsch, J. V. (1995). The need for action in sociocultural research. Cambridge: Cambridge University Press.

Wickman, P.-O. (2006). Aesthetic experience in science education: learning and meaning-making as situated talk and action. Mahwah: Lawrence Erlbaum Associates.

Wickman, P.-O. (2017). Back to the drawing board - examining the philosophical foundations of educational research on aesthetics and emotions. In A. Bellocchi, K. Otrel-Cass, \& C. Quigley (Eds.), Beyond cognition in science education: Considering the role of emotions, well-being, and aesthetics (pp. 9-37). New York: Springer. 
Wickman, P.-O., \& Östman, L. (2002). Learning as discourse change: a sociocultural mechanism. Science Education, 86, 1-23.

Wittgenstein, L. (1950/1978). Remarks on colour. Los Angeles: University of California Press.

Wittgenstein, L. (1953/1996). Philosophical investigations. Oxford: Blackwell.

Wittgenstein, L. (1966). Lectures and conversations on aesthetics, psychology and religious belief. Oxford: Blackwell. 